\title{
Floral biology of Stachytarpheta maximiliani Scham. (Verbenaceae) and its floral visitors
}

\author{
Ivana de Freitas Barbola ${ }^{1}$; Sebastião Laroca ${ }^{2}$; Maria Christina de Almeida² \& Elynton Alves do Nascimento ${ }^{3}$
}

\author{
${ }^{1}$ Departamento de Biologia Geral, Universidade Estadual de Ponta Grossa. Av. Carlos Cavalcanti, 4748, 84030-900 Ponta Grossa-PR, Brazil \\ ibarbola@yahoo.com.br \\ ${ }^{2}$ Universidade Federal do Paraná. Caixa Postal 19020, 81531-990 Curitiba-PR, Brazil. slaroca@netpar.com.br; chrisalm@ufpr.br \\ ${ }^{3}$ Departamento de Biologia, Faculdade de Filosofia, Ciências e Letras de Ribeirão Preto, Universidade de São Paulo. Av. Bandeirantes, 3900, \\ 14040-901 Ribeirão Preto-SP, Brazil. elynton@yahoo.com
}

\begin{abstract}
Floral biology of Stachytarpheta maximiliani Scham. (Verbenaceae) and its floral visitors. This study describes the reproductive system of Stachytarpheta maximiliani (Verbenaceae), including its floral biology, nectar and pollen availability and insect foraging patterns, identifying whose species act as pollinators. It was carried out in a Brazilian Atlantic rain forest site. Observations on the pollination biology of the Verbenaceae S. maximiliani indicate that their flowering period extends from September through May. Anthesis occurs from 5:30 a.m. to 5:00 p.m. and nectar and pollen are available during all the anthesis. Many species of beetles, hemipterans, flies, wasps, bees and butterflies visit their flowers, but bees and butterflies are the most frequent visitors. The flowers are generally small, gathered in dense showy inflorescences. A complex of floral characteristcs, such as violet-blue color of flowers, long floral tubes, without scents, nectar not exposed, high concentration of sugar in nectar (about 32\%), allowed identification of floral syndromes (melittophily and psicophily) and function for each visitor. The bees, Bombus morio, B. atratus, Trigonopedia ferruginea, Xylocopa brasilianorum and Apis mellifera and the butterflies Corticea mendica mendica, Corticea sp., Vehilius clavicula, Urbanus simplicius, U. teleus and Heraclides thoas brasiliensis, are the most important pollinators.
\end{abstract}

KEYWORDS. Apoidea; floral ecology; Lepidoptera; pollination.

RESUMO. Biologia floral de Stachytarpheta maximiliani Scham. (Verbenaceae) e seus visitantes florais. Este estudo descreve alguns aspectos do sistema reprodutivo de Stachytarpheta maximiliani (Verbenaceae), incluindo características da flor, disponibilidade de néctar e pólen e o padrão de forrageio dos insetos visitantes florais, em uma área de Floresta Atlântica, no sul do Brasil. Observações sobre sua biologia floral indicam que esta espécie tem um período de floração que se estende de setembro a maio, antese diurna (das 5:30h às 17:00h) e oferta de néctar e pólen praticamente durante todo o período de antese. Suas flores são visitadas por diferentes espécies de coleópteros, dípteros, hemípteros, himenópteros e lepidópteros, em busca de néctar e pólen, sendo que abelhas e lepidópteros são os mais freqüentes. Um complexo de características florais, em que se incluem flores de cor violeta-azulada, sem odor perceptível, corola infundibuliforme (longa e afilada), néctar não exposto, com alta concentração de açúcar (cerca de 32\%), acumulado na porção inferior do tubo da corola, constitui um elemento selecionador de visitantes. Tais características se enquadram nas síndromes de melitofilia e psicofilia, sendo as abelhas Bombus morio, B. atratus, Trigonopedia ferruginea, Xylocopa brasilianorum e Apis mellifera e os lepidópteros Corticea mendica mendica, Corticea sp., Vehilius clavicula, Urbanus simplicius, $U$. teleus e Heraclides thoas brasiliensis seus mais importantes polinizadores.

PALAVRAS-CHAVE. Apoidea; ecologia floral; Lepidoptera; polinização.

The genus Stachytarpheta Vahl (Verbenaceae), known commonly in Brazil by "gervão", includes about 100 species widely distributed in tropical and subtropical America, with few members in tropical Asia, Africa and Oceania. In Brazil, there are nearly 40 species, with diversity center in the high fields in the states of Minas Gerais, Bahia and Goiás (Atkins et al. 1996). They are shrubs or herbaceous plants, with whole alternate or opposite leaves. The flowers are generally small, gathered in dense showy inflorescences, of varied colours, from intense purple to a pale rose (Atkins et al. op. cit.).

Although some species are considered ornamental or medicinal, such as S. jammaicensis (L.) Vahl and S. cayennensis (Rich.) Vahl (Hirschmann \& Rojas de Arias 1990; Rodríguez \& Castro 1996), they occur usually as weed in crops and pasture.

There are a few studies about Stachytarpheta reproductive system, standing out some studies on floral rewards to the visitors and syndrome of pollination of sandbank plants, including S. cayennensis (Ormond et al. 1993). Evaluation of the pollen nutritive and attractive qualities of flowering plants includes two species of Stachytarpheta (Pinheiro et al. 1991); and observations about the foraging pattern of pollinators of S. mutabilis (Stone et al. 1988). Weather influence on abundance of floral visitants of S. glabra was investigated by Antonini et al. (2005). In the other groups in Verbenaceae, there are studies on floral biology and ecology of pollination of Lantana camara L. and L. trifolia L. (Schemske 1976); Verbena stricta Vent., V. hastata L. and V. urticifolia L. (Cruden et al. 1990); Vitex negundo L. (Reddy \& Reddi 1994); Duranta repens L. (Reddy \& Reddi 1996) and Gmelina asiatica L. (Reddi et al. 1996). 
This work describes the reproductive biology of $S$. maximiliani Scham., including its floral biology, nectar and pollen availability and insect foraging patterns, identifying whose species act as pollinators. This plant was chosen because it is very common in secondary vegetation areas and it has a long blooming period. Besides, some morphological characteristics of the flower, such as the tiny tubular corolla with non-exposed nectar accumulated in the basis of the corolla, permit to establish close relationships between flower and different pollinators, especially bees and butterflies.

\section{MATERIALS AND METHODS}

The study was carried out at the Instituto Agronômico do Paraná (IAPAR) Experimental Station, located in the city of Morretes (2530' S; 4849’ W), in a Brazilian Atlantic rain forest area.

The station is situated in a coluvio-aluvional plain area, about $200 \mathrm{~m}$ high. According to Klein (1979), the phytoecological region is Tropical Ombrofilous Forest in the Atlantic Slope of Southern Brazil, or Dense Ombrofilous Forest (Veloso et al. 1991). It presents thick forest vegetation, pluristratified, with epiphytes and vines.

The climate is pluvial tropical, in a transition tropical zone, ever humid, with the minimum temperature around $18^{\circ} \mathrm{C}$, without night frost in winter (Paraná 1987).

Nowadays, part of the area has been suffering modifications in its original vegetation due to agricultural and livestock researches of IAPAR, and to the illegally "palmito" (heart of palm) extractivism. Native forest is endangered too by cultures of rice and pasture, frequent land clearings and a buffalo's trampling. Near to the pickets for the cattle and barns it is observed a variety of shrub or herbaceous weed plants including S. maximiliani.

Research was carried out from April of 1995 to December of 1997, in two areas bordering the forest, next to a pasture. Voucher specimens of $S$. maximiliani are housed in the Herbarium of the State University of Ponta Grossa, Paraná (HUPG).

To understand the floral biology of "gervão", many experiments were carried out, among them: record of anthesis and flowering period, evaluation of the intensity of blooming, evaluation of pollen and nectar availability and observation on the visitors behaviour, following Faegri \& van der Pijl (1979) and Dafni (1992).

Measurements of the flower size were made concerning to the diameter of the corolla (in its wider part), its depth and form (circular, elliptical, etc.).

Twenty five plants were marked and their floral phenology recorded. The beginning peak and end of flowering, as well as the relative flowering intensity (= average number of flowers/ inflorescence $\mathrm{x}$ average number of inflorescences/individual) were registered (following Dafni 1992). The flowering magnitude was measured from the percentage of simultaneously open flowers in the time (a day, in this case, due to anthesis time of "gervão”).

During anthesis, it was evaluated nectar availability (by volume) and sugar concentration (using a light refractometer Bausch \& Lomb). Due to flower damage during nectar collection, it was impossible to quantify this parameter precisely. So, the nectar volume was estimated according to the space occupied into the corolla tube: just traces, a quarter, or almost half of the corolla. To analyze this, the inflorecences with buds were put on bags at evening; in the following day, hour by hour (all day long) the inflorescences was pulled out from the bags and the nectar amount and sugar concentration were measured, from at least 20 flowers of different marked individuals. The nectar amount produced by the flowers was measured from the average volume produced by flower, using a $10 \mu \mathrm{l}$ micropipette.
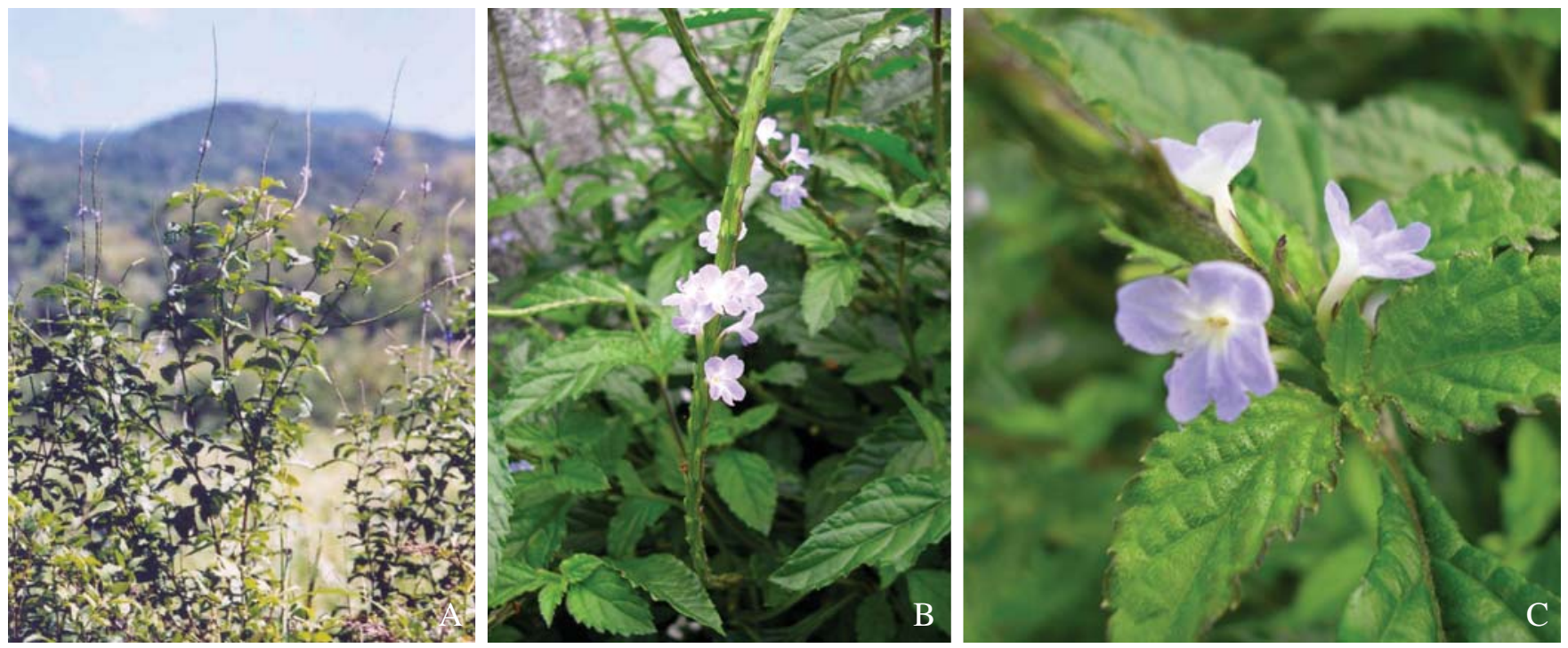

Fig. 1. Stachytarpheta maximiliani habit (A); details of the inflorescence (B) and flower (C). 
Table I. Flower measurements (in $\mathrm{mm}$ ) in Stachytarpheta maximiliani (Verbenaceae), collected at Experimental Station II, IAPAR, Morretes, PR. $(\mathrm{N}=20$; average \pm standard error $)$

\begin{tabular}{cccc}
\hline & Corolla depth & Tube diameter & Flower diameter \\
\hline amplitude & $6.9-9.5$ & $1.1-1.9$ & $8.1-9.9$ \\
average & $8.2 \pm 1.2$ & $1.4 \pm 0.3$ & $8.7 \pm 1.3$ \\
\hline
\end{tabular}

The availability and viability of the pollen grain were tested in field and in the laboratory. The grains, collected hour by hour, all day long, since anthesis until senescence, were tested with acetic carmim 15\% and observed at the microscope.

Floral insects visitors on "gervão" were observed to settle their potential as pollinators. We recorded their behaviour on the flower, flying pattern across inflorescences, time of visit and kind of resource collected. Captured individuals were pinned and identified. Measures of body size and tongue lenght (mm) were obtained from estereomicroscope (Zeiss), with micrometric ocular.

\section{RESULTSANDDISCUSSION}

Floral morphology of $S$. maximiliani. S. maximiliani is a perennial shrub plant, 1,5 m tall. Flowers are tubular (according with classification of Faegri \& van der Pijl, 1979), small (medium $8,2 \mathrm{~mm}$ long), actinomorph, pentamer, formed by a long and narrow tube (Table I), blue-violet (Fig. 1). They are inserted in a long inflorescence with staggered blooming.

Floral Phenology. In Morretes, "gervão” presents a relatively long flowering period from September to May, peaking between November and January, when insect activity is high. After February there is a decline in the number of open flowers per plant and from June to August flowers are almost completely absent. They possess non-exposed nectar, accumulated in the inferior portion of the corolla tube. Another shrub of this genera, Stachytarpheta glabra presents more brief period of flowering, from January to June at ferruginous fields of Minas Gerais, with flowering peak between February to April (Antonini et al. 2005).

Regarding to relative intensity of blooming, each bloom produces about 504 flowers/individual (from 24 to 1,100 flowers/plant). This value comprises the total number of flowers produced by each individual of "gervão" during the flowering period and represents the mean number of flowers by inflorescence (42 flowers/inflorescence) multiplied by average number of inflorescences by individual (12 inflorescences/individual). At peak blossom period, it was observed from 2 to 14 open flowers simultaneously by inflorescence by day, that represents ca. $12 \%$ of flowers in anthesis by plant.

These values represents a measure of the spatial distribution of the floral resource that can influence the patterns of pollen flow was evaluated e, together with the blooming type, synchronous or sequential, allows to estimate the offer of floral resources (nectar and pollen) to visitors and to determine, in part, the reproductive strategy of a plant. In $S$. maximiliani, the blooming type is part sequential part synchronous, and the anthesis in the inflorescence, occurs in parcels from the basal portion towards the apex. However, a great number of flowers could open simultaneously in the different individuals. Their clumped distribution is very attractive to visitors. The positive relationship between flower and inflorescence abundance and the number of floral visitants has been discussed by many authors, among them, Schmitt (1983), Klinkhamer \& de Jong (1993), Salimenta-Pires \& Giulietti (1998) and Antonini et al. (2005) concerning that higher inflorescences number provide greater advertising area to the plant, and this added to the high number of open flowers simultaneously, attract more attention of visitants and potential pollinators.

Anthesis. The flowers begin opening at dawn, between 4:30 and 5:30 a.m. They open from 2 to 14 flowers by each blossom every day (the more common were 3 or 4 ). Fading occurs from the 3:00 up to the 5:00 p.m. Flower longevity is approximately 12 hours, which was also observed by Bawa et al. (1985) for other tropical species.

Nectar: the low quantity of nectar secreted (less than $10,0 \mu \mathrm{l} /$ flower during anthesis), forces pollinators to visit many flowers from different plants. Since the beginning of anthesis until almost 8:00 a.m. there is no nectar availability (or just traces); from 8:00 to noon it was observed a quarter of corolla tube of nectar; from 12:00 until 2:30 p.m., half tube was filled.

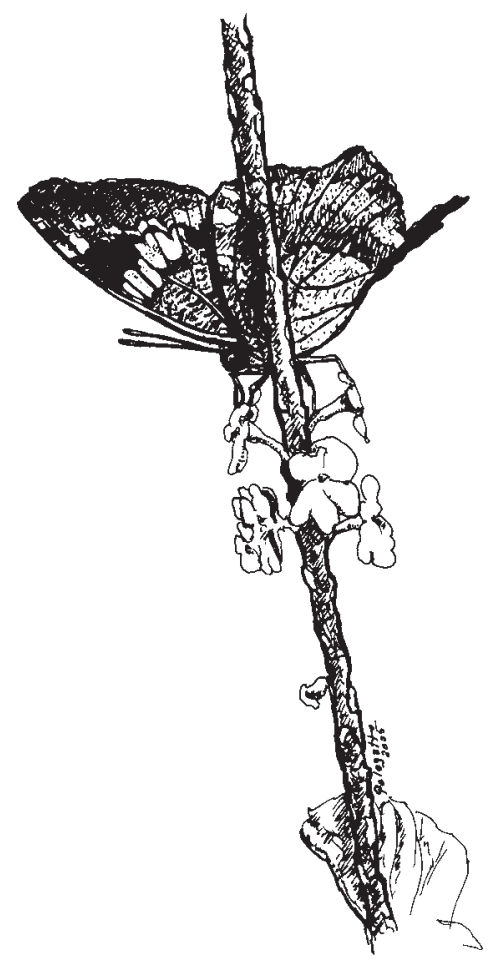

Fig. 2. Stachytarpheta maximiliani visited by Anartia amathea roeselia (Nymphalidae). 
Table II. Insect visitors in flowers of Stachytarpheta maximiliani (Verbenaceae), at Experimental Station II - IAPAR, Morretes, PR, from April 1995 to December 1997. Visit frequency: R (for less than 10 visits), M (uncommon, from 10 to 20 visits), C (common, more than 20 visits); $r$ (restrict to a specific period in the year, or even just one collect), $\mathrm{f}$ (frequent for a longer period, more than two month). Resource collected: $\mathrm{N}$ (nectar), P (pollen), petal (eating petals), nt (nectar thieves, perforating the corolla basis), (*) presence of another pollen over the body, (?) uncertain.

\begin{tabular}{|c|c|c|c|}
\hline \multicolumn{4}{|l|}{ Order } \\
\hline Family & pollen deposition on & visit & Resource \\
\hline Specie & insect body & frequency & collected \\
\hline Chrysomelidae sp.1 & $(*)$ & $\mathrm{Rr}$ & $\mathrm{P} /$ petal \\
\hline Coleoptera sp.2 & & $\mathrm{Rr}$ & $\mathrm{N}$ \\
\hline \multicolumn{4}{|l|}{ DIPTERA } \\
\hline Acroceridae sp.2 & & $\mathrm{Rr}$ & $\mathrm{N}$ \\
\hline Bombyliidae sp.1 & buccal apparatus & $\mathrm{Mr}$ & $\mathrm{N}$ \\
\hline Bombyliidae sp. 2 & & $\mathrm{Mr}$ & $\mathrm{N}$ \\
\hline Syrphidae sp.1 & $(*)$ & $\mathrm{Rr}$ & N P \\
\hline \multicolumn{4}{|l|}{ HEMIPTERA } \\
\hline Hemiptera sp.1 & fore legs & $\mathrm{Mr}$ & $\mathrm{N}(\mathrm{nt})$ \\
\hline Hemiptera sp.2 & fore legs & $\mathrm{Mr}$ & $\mathrm{N}$ \\
\hline \multicolumn{4}{|l|}{ HYMENOPTERA } \\
\hline \multicolumn{4}{|l|}{ Andrenidae } \\
\hline Psaenythia chrysorhoea (Holmberg, 1884) & buccal apparatus (*) & $\mathrm{Rr}$ & N P \\
\hline \multicolumn{4}{|l|}{ Anthophoridae } \\
\hline Centris tarsata Smith, 1874 & $(*)$ & $\mathrm{Rr}$ & $\mathrm{N}$ \\
\hline Ceratina asuncionis Strand, 1910 & $(*)$ & $\mathrm{Mr}$ & N P \\
\hline Ceratina sp.2 & $?$ & $\mathrm{Rr}$ & $\mathrm{N}$ \\
\hline Ceratina sp.3 & $?$ & $\mathrm{Rr}$ & $\mathrm{N}$ \\
\hline Lophopedia sp.2 & & $\mathrm{Rr}$ & N P \\
\hline Melissodes nigroaenea (Smith, 1854) & $(*)$ & $\mathrm{Rr}$ & N P \\
\hline Monoeca sp. & Head $(*)$ & $\mathrm{Mr}$ & \\
\hline Nomada sp.3 & ? & $\mathrm{Rr}$ & $\mathrm{N}$ \\
\hline Exomalopsis aff. vernoniae & buccal apparatus & Rf & N P \\
\hline Thygater analis (Lepeletier, 1841) & buccal apparatus $(*)$ & $\mathrm{Rr}$ & N P \\
\hline Xylocopa brasilianorum (Linnaeus, 1767) & scopa & $\mathrm{Mr}$ & N P \\
\hline \multicolumn{4}{|l|}{ Apidae } \\
\hline Apis mellifera Linnaeus, 1758 & previous legs $(*)$ & Cf & N P \\
\hline Bombus atratus Franklin, 1913 & torax (ventral) & Cf & N P \\
\hline Bombus brasiliensis Lepeletier, 1836 & ? & Cf & N P \\
\hline Bombus morio (Swederus, 1787) & buccal ap., torax $(*)$ & Cf & N P \\
\hline Euglossa ignita Dressler, 1982 & ? & $\mathrm{Rr}$ & N P \\
\hline Eulaema nigrita Lepeletier, 1841 & $(*)$ & $\mathrm{Rr}$ & $\mathrm{N}$ \\
\hline Partamona helleri (Friese, 1900) & buccal apparatus & $\mathrm{Rr}$ & N P \\
\hline Trigona spinipes Fabricius, 1793 & & $\mathrm{Rr}$ & $\mathrm{N}(\mathrm{nt})$ \\
\hline \multicolumn{4}{|l|}{ Halictidae } \\
\hline Augochlora esox (Vachal, 1911) & buccal ap., scopa (*) & Rf & $\mathrm{NP}$ \\
\hline Augochloropsis brachycephala Moure, 1943 & $(*)$ & Rf & $\mathrm{N}(\mathrm{nt})$ \\
\hline Pseudaugochloropsis graminea (Fabricius, 1804) & $(*)$ & Rf & $\mathrm{N}(\mathrm{nt})$ \\
\hline \multicolumn{4}{|l|}{ Megachilidae } \\
\hline Megachile nudiventris Smith, 1853 & buccal ap., head (*) & $\mathrm{Rr}$ & N P \\
\hline Vespidae sp.1 & buccal apparatus & $\mathrm{Rr}$ & N P \\
\hline Scoliidae sp.1 & torax (ventral) & $\mathrm{Rr}$ & N P? \\
\hline \multicolumn{4}{|l|}{ LEPIDOPTERA } \\
\hline \multicolumn{4}{|l|}{ Hesperiidae } \\
\hline Anthoptus epictetus Fabricius, 1793 & & Cf & $\mathrm{N}$ \\
\hline Callimormus sp.1 & $(*)$ & Cf & $\mathrm{N}$ \\
\hline Corticea mendica mendica Mabilde, 1897 & buccal apparatus & Cf & $\mathrm{N}$ \\
\hline Corticea noctis Plötz, 1883 & & Cf & $\mathrm{N}$ \\
\hline
\end{tabular}




\begin{tabular}{|c|c|c|c|}
\hline \multicolumn{4}{|l|}{ Order } \\
\hline Family & pollen deposition on & visit & Resource \\
\hline Specie & insect body & frequency & collected \\
\hline Corticea sp.1 & buccal apparatus & Cf & $\mathrm{N}$ \\
\hline Epargireus sp.1 & ? & Cf & $\mathrm{N}$ \\
\hline Eutychide olimpia Plötz & & Cf & $\mathrm{N}$ \\
\hline Moris geisa geisa Möschil., 1878 & & $\mathrm{Cf}$ & $\mathrm{N}$ \\
\hline Panosquina sylvicola Schaffer, 1865 & ? & Cf & $\mathrm{N}$ \\
\hline Pirgus oileus orcus Stoll, 1780 & & Cf & $\mathrm{N}$ \\
\hline Pompeius pompeius Latreille, 1824 & & Cf & $\mathrm{N}$ \\
\hline Urbanus simplicius Stoll, 1790 & ? & Cf & $\mathrm{N}$ \\
\hline Urbanus teleus Hübner, 1821 & buccal apparatus / $(*)$ & Cf & $\mathrm{N}$ \\
\hline Vehilius clavicula Plötz & buccal apparatus / (*) & Cf & $\mathrm{N}$ \\
\hline Vehilius stictomenes stictomenes Butler, 1877 & & Cf & $\mathrm{N}$ \\
\hline Zariaspes mys Hübner, 1808 & & Cf & $\mathrm{N}$ \\
\hline \multicolumn{4}{|l|}{ Nymphalidae } \\
\hline Anartia amathea roeselia Eschscholtz, 1821 & & Mf & $\mathrm{N}$ \\
\hline Heliconius erato phyllis Fabricius, 1775 & & $\mathrm{Cr}$ & $\mathrm{N}$ \\
\hline Heliconius sara apseudes Hübner, 1806 & $(*)$ & $\mathrm{Cr}$ & $\mathrm{N}$ \\
\hline \multicolumn{4}{|l|}{ Papilionidae } \\
\hline Heraclides thoas brasiliensis Roimsch \& Jordan, 1906 & buccal apparatus & $\mathrm{Cr}$ & $\mathrm{N}$ \\
\hline \multicolumn{4}{|l|}{ Pieridae } \\
\hline Ascia monuste orseis Godart, 1819 & $?$ & $\mathrm{Mr}$ & $\mathrm{N}$ \\
\hline
\end{tabular}

From 3:00 p.m. the availability declines, probably due to reabsorption by the plant or evaporation. The sugar concentration was $32 \% \pm 5(n=50)$.

According to Vicente et al. (2002) and Antonini et al. (2005), the anthesis of S. glabra keeps ca. 10 hours and wich flower produce until $25 \mu \mathrm{l}$ of nectar/day.

Pollen viability: in this study pollen viability is high (more than $90 \%$ ) in the period from 9:00 a.m. to 1:00 p.m. In the first hours in the morning or in the afternoon, pollen viability decreases to $50 \%$ until wilting, although can be observed pollen grains in the flower.

Scent: "gervão" flowers do not have perceptible smell along the day. According with Antonini et al. (2005), S. glabra flowers do not have perceptible smell too. This odour absence, such as the color (intense bluish-violet) and the corolla shape indicate pollination by diurnal visitants.

Floral visitors of $\boldsymbol{S}$. maximiliani. The flowers of $S$. maximiliani are intensively visited by different insect groups since the first hours of the morning until the afternoon. The tubular flower requires specialized nectar-feeding insects (Faegri \& van der Pijl 1979; Ormond et al. 1993; Antonini et al. 2005). So, visitors with long thin tongues could collect nectar at the corolla basis more easily, and pollen as well, when compared to short-tongue insects.

Table II lists visitors and Table III presents the measures of the body and the tongue of the most frequent species. $S$. maximiliani attracts a great number of insects (59 species were captured on the flowers), with variable body size and tongue length, with certain predominancy of long-tongue insects. Bees and butterflies were the most abundant in species number and individuals. These groups, having long slender tongues, are capable to reach nectar and pollen, generally showing pollen grains in the buccal apparatus, head or even the ventral portion of thorax due to the position of the anthers on the inner surface of corolla.

Beetles presented few individuals of two small-sized body and short-tongue species visiting the flowers, without pollen on their bodies. In Diptera, some Bombyliidae showed pollen in the buccal apparatus, visiting briefly, in general, just one flower for plant. Only one individual of Acroceridae showed pollen in the ventral portion of thorax, while the two Syrphidae individuals captured had varied polen over their bodies. Adults and nymphs of Hemiptera remained over the flowers for a long time, probably collecting nectar; sometimes it was observed individuals perforating the corolla basis and were found pollen grains deposited in the forelegs.

In one occasion, several individuals of a small long-beaked hummingbird, were observed collecting nectar of several flowers along the day.

By the data, one could analyze the role of several visitors in "gervão" flowers, at Morretes, as follows:

Coleoptera, Diptera (Acroceridae and Syrphidae) and Hymenoptera (Scoliidae), can be considered nectar thieves due to low frequency of visits and because they do not reach the reproductive structures of the flowers.

Hemiptera and the bees A. brachycephala, T. spinipes and specially $P$. graminea, due to their behaviour and abundance, are nectar thieves, perforating the corolla basis without touching the anthers and stigma. 
Table III. Measurements of the body and tongue lenght of some insect visitors in flowers of Stachytarpheta maximiliani (Verbenaceae), at Experimental Station II - IAPAR, Morretes, PR, collected from April 1995 to December 1997. ( points aproximate lenght).

\begin{tabular}{|c|c|c|c|c|c|}
\hline Insect species & $\begin{array}{c}\text { Body lenght } \\
\text { (mm) }\end{array}$ & $\begin{array}{l}\text { Tongue lenght } \\
\text { (mm) }\end{array}$ & Insect species & $\begin{array}{l}\text { Body lenght } \\
(\mathrm{mm})\end{array}$ & $\begin{array}{l}\text { Tongue lenght } \\
\text { (mm) }\end{array}$ \\
\hline Diptera & & & Hymenoptera & & \\
\hline Acroceridae sp.1 & 8,0 & 5,6 & Apis mellifera & 14,0 & 4,7 \\
\hline Bombyliidae sp.1 & 21,0 & 9,0 & Augochlora esox & 11,0 & 4,2 \\
\hline Lepidoptera & & & Augochloropsis brachycephala & 12,0 & 2,9 \\
\hline Anartia amathea roeselia & 19,0 & 9,2 & Bombus atratus & 18,0 & 10,0 \\
\hline Ascia monuste orseis & 23,0 & $\sim 15,0$ & Bombus morio & 23,0 & 10,4 \\
\hline Corticea mendica mendica & 14,0 & 12,0 & Ceratina asuncionis & 10,0 & 2,2 \\
\hline Corticea sp.1 & 12,0 & $\sim 9,0$ & Lophopedia sp. & 10,0 & 5,0 \\
\hline Eutychide olimpia & 18,0 & $\sim 13,0$ & Nomada sp. & 11,0 & 5,2 \\
\hline Heraclides thoas brasiliensis & 31,0 & $\sim 23,0$ & Psaenythia crysorhoea & 14,0 & 6,9 \\
\hline Panosquina sylvicola & 17,0 & 14,0 & Pseudaugochloropsis graminea & 13,0 & 5,8 \\
\hline Urbanus simplicius & 21,0 & $\sim 17,0$ & Thygater analis & 13,0 & 8,6 \\
\hline Urbanus teleus & 20,0 & 15,0 & Xylocopa brasilianorum & 23,0 & 8,8 \\
\hline
\end{tabular}

Some bee species (as Psaenythia chrysorhoea, Centris tarsata, Thygater analis and Megachile nudiventris), Vespidae and Bombyliidae, for their low frequency of visits, and for the usual absence of pollen over their bodies, would be just occasional pollinators. Some Lepidoptera, such as Anthoptus epictetus, Epargireus sp.1 and Anartia amathea roeselia, (Fig. 2) also do not usually have pollen on their bodies and can be considered just occasional pollinators.

B. morio, B. atratus, T. ferruginea, $X$. brasilianorum and A. mellifera, for their high frequency and steadiness (specially B. morio and T. ferruginea), their behaviour of reaching reproductive structures of flowers and the great amount of pollen that they transport in their body in contact with stigma, can be considered important pollinators of "gervão". Among Lepidoptera, mainly the species C. mendica mendica, Corticea sp., V. clavicula, $U$. simplicius, $U$. teleus and $H$. thoas brasiliensis, for their high frequency and steadiness, their behaviour handling flowers and touching anthers and stigmas, although few pollen have been observed on their bodies, also are involved in the "gervão" pollination.

Psicophylly and mellitophyly seems to be usual in Verbenaceae. Stone et al. (1988), studying the floral visitants behaviour of $S$. mutabilis, in Papua New Guinea, identifyed two species of Papilionidae, Ornithoptera priamus poseidon and Papilio ulysses, and one of Anthophoridae, Amegilla sapiens as the main pollinators of the shrub.

Ormond et al. (1993), evaluating the kind of pollination among several species in a sand bank vegetation in Itaipuaçu (RJ - Brazil), suggest the occurrence of psychophylly (pollination by lepidopterans) in $S$. canescens HBK and $S$. cayennensis, supported by a set of morphological characteristics presented.

Antonini et al. (2005) recorded 28 species of flower-visiting insects of S. glabra, wich two bee species, Eulaema nigrita e Apis mellifera and some Lepidoptera were considered as potential pollinators, whereas Bombus atratus, Oxaea flavescens, some Vespidae e Halictidae were recognized as nectar thieves.

In other Verbenaceae, different authors found bees, wasps, butterflies and moths as their primary pollinators. Schemske (1976) observed several species of Hesperiidae (specially Urbanus spp. and Pyrgus spp.), Pieridae, Papilionidae, Nymphalidae (mainly Anartia jatrophae), Danaidae and Lycaenidae visiting Lantana camara and $L$. trifolia. Reddy \& Reddi (1994) have found 22 insect species visiting Vitex negundo, being the bees Apis cerana indica, Amegilla sp. and Ceratina sp., and the wasps Sphex sp., Delta sp. and Ropalidia spatulata their principal pollinators. Studying the reproductive system of Clerodendrum infortunatum, Reddy \& Reddi (1995) identified three pollinator species of Papilionidae: Papilio polytes, $P$. polymnestor and Atrophaneura hector. These two authors, in 1996, observed 30 insect species visiting flowers of Duranta repens, of which bees, wasps, butterflies and moths were effective pollinators. Reddi et al. (1996) considered the flowers of Gmelina asiatica pollinated by large bees of the genus Xylocopa, although other insect species also visit them.

The results of the current study in the Atlantic Forest are in conformity with the observations for the Verbenaceae, in which several diurnal species of insects, mainly bees and lepidopterans, visit their flowers searching for nectar and pollen. A set of characteristics in this plant, such as bluishviolet flowers, no perceptible smell, long tubular corolla, and non-exposed nectar deposited at the bottom of the corolla tube, strongly select the visitors and pollinators, demanding a more elaborated intrafloral behaviour. Bees and lepidopterans, with their long tongues, are able to reach the bottom of the corolla and take the nectar (and pollen, in the case of the bees). At the same time, they could reach the anthers and stigma using several parts of their bodies, being the more important visitors pollinating this species. 
Acknowledgements. We are thanks to Olavo Guimarães for the determination of the S. maximiliani, to Danúncia Urban for the identification of some species of Apoidea, and to Marcelo Lopes Silva for the identification of some species of Lepidoptera. We also thanks Paulo S. Oliveira for the valuable comments on the manuscript and Cleber M. Polegatto for the drawing.

\section{REFERENCES}

Antonini, Y.; H. G. Souza; C. M. Jacobi \& F. B. Mury. 2005. Diversidade e comportamento dos insetos visitantes florais de Stachytarpheta glabra Cham. (Verbenaceae), em uma área de campo ferruginoso, Ouro Preto, MG. Neotropical Entomology 34: 555--564.

Atkins, S.; R. J. V. Alves \& J. Kolbeck. 1996. Plants in peril 23: Stachytarpheta sellowiana. Curtis's Botanical Magazine 13: 33-35.

Bawa, K. S.; S. H. Bullock; D. R. Perry; R. E. Coville \& M. H. Grayum. 1985. Reproductive biology of tropical lowland rain forest trees. II. Pollination systems. American Journal of Botany 2: 346356.

Cruden, R. W.; K. K. Baker; T. E. Cullinan; K. A. Disbrow; K. L. Douglas; J. D. Erb; K. J. Kirsten; M. L. Malik; E. A. Turner; J. A. Weier \& S. R. Wilmot. 1990. The mating systems and pollination biology of three species of Verbena (Verbenaceae). Journal of Iowa Academy of Science 97: 178-183.

Dafni, A. 1992. Pollination ecology: a pratical approach. New York. Oxford University Press, New York, 250 p.

Faegri K. \& L. van der Pijl. 1979. The principles of pollination ecology. Oxford, Pergamon Press, $3^{\text {nd }}$ ed. 291 p.

Hirschmann, G. S. \& A. Rojas de Arias. 1990. A survey of medicinal plants of Minas Gerais, Brazil. Journal of Etnopharmacology 29: $159-172$.

Klein, R. M. 1979. Ecologia da flora e vegetação do vale do Itajaí. Sellowiana 31: $1-164$

Klinkhamer, P. G. L. \& T. J. de Jong. 1993. Attractiveness to pollinators: A plant's dilemma. Oikos 66: 180-184.

Ormond, W. T.; M. C. B. Pinheiro; H. A. Lima; M. C. R. Correia \& M. L. Pimenta. 1993. Estudo das recompensas florais das plantas da
Restinga de Maricá - Itaipuaçu, RJ. I. - Nectaríferas. Bradea 6: 179-195.

Paraná. Instituto de Terras, Cartografia e Floresta. 1987. Planos global e específico de gerenciamento da área especial de interesse turístico do Marumbi. Curitiba. 105 p.

Pinheiro, M. C. B.; W. T. Ormond; H. A. Lima; M. C. R. Correia \& M. L. Pimenta. 1991. Estudo do amido no pólen das Angiospermae. Boletim do Museu Nacional, Nova Série, Botânica 86: 1-22.

Reddy, T. B. \& C. S. Reddi. 1994. Pollination ecology of Vitex negundo (Verbenaceae). Proceedings of the Indian Natural Science Academy, Part B, Biological sciences 60: 57-66.

Reddy, T. B. \& C. S. Reddi. 1995. Butterfly pollination of Clerodendrum infortunatum (Verbenaceae). Journal of the Bombay Natural History Society 92: 166-173.

Reddy, T. B. \& C. S. Reddi. 1996. Pollination ecology of Duranta repens (Verbenaceae). Journal of the Bombay Natural History Society 93: 193-201.

Reddi, C. S.; R. K. Das; R. J. S. Aluri \& J. B. Aluri. 1996. Sexual system and pollination ecology of Gmelina asiatica L. (Verbenaceae). Journal Palynology 32: 41-50.

Rodríguez, S. M. \& O. Castro. 1996. Evaluación farmacológica y química de Stachytarpheta jamaicensis (Verbenaceae). Revista de Biologia Tropical 44: 353-359.

Salimena-Pires, F. R. \& A. M. Giulietti. 1998. Flora da Serra do Cipó, Minas Gerais: Verbenaceae. Boletim de Botânica da Universidade de São Paulo 17: 155-186.

Schemske, D. W. 1976. Pollinator specificity in Lantana camara and L. trifolia (Verbenaceae). Biotropica 8: 260-264.

Schmitt, J. 1983. Flowering plant density and pollinator visitation in Senecio. Oecologia 60: 97-102.

Stone, C. N.; J. N. Amos; T. F. Stone; R. L. Knight; H. Gay \& F. Parrott. 1988. Thermal effects on activity patterns and behavioural switching in a concource of foragers on Stachytarpheta mutabilis (Verbenaceae) in Papua New Guinea. Oecologia 77: 56-63.

Veloso, H. P.; A. L. R. Rangel-Filho \& J. C. A. Lima. 1991. Classificação da vegetação brasileira, adaptada a um sistema universal. IBGE, Rio de Janeiro, 123 p.

Vincent, C. R.; C. M. Jacobi \& Y. Antonini. 2002. Diversidade na adversidade. Ciência Hoje 31: 64-67. 